\title{
A Review on Land Use and Land Cover Change in Ethiopian Basins
}

\author{
Motuma Shiferaw Regasa ${ }^{1}$, Michael Nones ${ }^{1, * \mathbb{C}}$ and Dereje Adeba ${ }^{2}$ \\ 1 Department of Hydrology and Hydrodynamics, Institute of Geophysics Polish Academy of Sciences, \\ 01-452 Warsaw, Poland; mregasa@igf.edu.pl \\ 2 Department of Hydraulic and Water Resources Engineering, College of Engineering and Technology, \\ Wollega University, PO Box 395 Nekemte, Ethiopia; mo_dereje2018@yahoo.com \\ * Correspondence: mnones@igf.edu.pl
}

Citation: Regasa, M.S.; Nones, M.;

Adeba, D. A Review on Land Use and Land Cover Change in Ethiopian Basins. Land 2021, 10, 585. https:// doi.org/10.3390/land10060585

Academic Editor: Francisco

Manzano Agugliaro

Received: 10 May 2021

Accepted: 31 May 2021

Published: 1 June 2021

Publisher's Note: MDPI stays neutral with regard to jurisdictional claims in published maps and institutional affiliations.

Copyright: (c) 2021 by the authors. Licensee MDPI, Basel, Switzerland. This article is an open access article distributed under the terms and conditions of the Creative Commons Attribution (CC BY) license (https:/ / creativecommons.org/licenses/by/ $4.0 /)$.

\begin{abstract}
Land Use Land Cover (LULC) changes analysis is one of the most useful methodologies to understand how the land was used in the past years, what types of detections are to be expected in the future, as well as the driving forces and processes behind these changes. In Ethiopia, Africa, the rapid variations of LULC observed in the last decades are mainly due to population pressure, resettlement programs, climate change, and other human- and nature-induced driving forces. Anthropogenic activities are the most significant factors adversely changing the natural status of the landscape and resources, which exerts unfavourable and adverse impacts on the environment and livelihood. The main goal of the present work is to review previous studies, discussing the spatiotemporal LULC changes in Ethiopian basins, to find out common points and gaps that exist in the current literature, to be eventually addressed in the future. A total of 25 articles, published from 2011 to 2020, were selected and reviewed, focusing on LULC classification using ArcGIS and ERDAS imagine software by unsupervised and maximum likelihood supervised classification methods. Key informant interview, focal group discussions, and collection of ground truth information using ground positioning systems for data validation were the major approaches applied in most of the studies. All the analysed research showed that, during the last decades, Ethiopian lands changed from natural to agricultural land use, waterbody, commercial farmland, and built-up/settlement. Some parts of forest land, grazing land, swamp/wetland, shrubland, rangeland, and bare/ rock out cropland cover class changed to other LULC class types, mainly as a consequence of the increasing anthropogenic pressure. In summary, these articles confirmed that LULC changes are a direct result of both natural and human influences, with anthropogenic pressure due to globalisation as the main driver. However, most of the studies provided details of LULC for the past decades within a specific spatial location, while they did not address the challenge of forecasting future LULC changes at the watershed scale, therefore reducing the opportunity to develop adequate basin-wide management strategies for the next years.
\end{abstract}

Keywords: Africa; Ethiopia; geographic information systems; land use land cover change; remote sensing

\section{Introduction}

Land use is defined as how the land is utilised by people and their habitats, usually with an accent on a functional role of land for economic activities, whereas land cover is a physical characteristic of the Earth's surface [1,2]. Land use land cover (LULC) dynamics are a well-known, accelerating, and substantial process, mostly driven by human activities, that is contributing significantly to forest fragmentation, land degradation, and biodiversity loss [3,4]. Land use land cover changes (LULCCs) analysis is one of the most used techniques to understand how the land was used in the past years, what types of detections are to be expected in the future, as well as the driving forces and processes 
behind these changes $[3,4]$. Besides natural variations, the increasing human population is driving modifications of the Earth's land surface that are unprecedented, and evidence is present on a global scale [5]. Therefore, there is the need for better evaluation of changes in the land cover (namely, the biophysical attributes of the Earth's surface) and land use for human purposes to understand the past variations and depict future trends for the coming decades.

LULCCs are so persistent that, when aggregated globally, they expressively affect strategic aspects of Earth's system functioning. They directly impact biotic diversity worldwide, contribute to local and regional climate change as well as global climate warming, and are one of the primary sources of soil degradation. By altering ecosystem services at the local and regional scales, LULCCs affect the ability of biological systems to support and adapt to human needs [6-8]. Indeed, the major modifications of LULC worldwide could be related to the intense agricultural development and the growing population [9].

Similar to the rest of the world, East Africa (Horn of Africa) is not an exception to these land use land cover changes (e.g., [10-13]). In particular, very rapid changes are clearly recognisable in Ethiopia, due to the population pressure, resettlement programs, climate change, and other human and nature-induced driving forces. Similar to other countries, anthropogenic activities are the most significant factors adversely changing the natural status of the Ethiopian landscape [12], involving detrimental and adverse impacts on the natural environment and livelihood [14-16]. The land is a critical resource for the livelihood of East Africans, and there has been a steady decline in the size of land holdings per household. Following the demand for land, LULCCs in this region have resulted in a decline of natural forests to human settlements, urban centres, farmlands, and grazing lands [17]. Between 1990 and 2015, the East African forest cover decreased annually by about $1 \%$, while the human population increased at an average annual rate of around 2\% [10]. As pointed out by Dibaba et al. [18], factors such as biophysical, socioeconomic, institutional, technological, and demographic, contributed to LULCCs, which leads to a decline in the agricultural yield and a loss of biodiversity in the entire upper Blue Nile Basin, but significantly in the Finchaa sub-basin in the Oromia Regional State, Ethiopia. The authors also pointed out that extended aridity and persistent drought, land and soil degradation, as well as the decline of water resources in general, are the major consequences of LULCCs at the regional scale.

Forest disturbance and the subsequent conversion to other LULC classes (such as grazing land, agricultural land, bare land, pasture, or settlement areas) could modify the hydrologic cycle at the local scale, involving significant effects on water yields, water quality, and streamflow dynamics $[19,20]$. The rapid rate of deforestation is mainly occurring because of several reasons such as unsustainable large and small scale agriculture, forest fire, migration and population growth, illegal logging for construction purposes, charcoal and fuelwood production for cooking, and poor resource management [21], namely, deforestation, which is connected to the increased occurrence of shifting cultivators, triggering mechanisms that invariably involve changes in land development and new policies by the national governments that push migrants into sparsely occupied areas [8]. Focusing on the Horn of Africa, the main forest types that have undergone this decrease are tropical rain and dry forests, tropical shrubs, tropical maintain the forest, and mangrove forests, while there have been intensive efforts to establish plantation forests [10]. Land policy in developing countries such as Ethiopia is considered a crucial part of the overall development policy that the national governments need for assuring rapid economic growth and poverty mitigation, regardless of the natural resources management [22].

Ethiopia is historically passed significant dynamics in LULC for many decades. However, nowadays, LULCCs and degradation are increasing at an alarming rate, playing a significant role in the increasing rate of soil erosion. The need for more cultivated lands has negatively affected the presence of forest and grasslands, eventually fostering soil erosion [23]. Environmental conversions and changes can be mainly attributed to various 
adverse human actions such as the expansion of farm plots at the expense of agricultural lands, massive fuelwood and charcoal production, overgrazing, and encroachment of farmsteads into vegetated lands. According to Tefera [12], ecologically, Ethiopia is characterised by a rich but shrinking diversity in biological resources such as forest, woody and grassy lands, shrubs, varied wildlife, and fertile soil. It is also renowned for its massive mountain ranges, high flat plateaus, deep gorges, river valleys, lowland plains, extensive wetlands, and deserts. Landscape degradation by soil erosion has increased considerably in the Ethiopian highlands since the deforestation of the natural mountain forests and the cultivation of large areas, resulting in serious danger to the Ethiopian population [24,25]. This also affects the water balance of an area by changing the balance between rainfall, evaporation, infiltration, and runoff. Based on the observed trends, it is clear that a systematic analysis of LULCC is crucial to exactly comprehend the extent of the changes and take necessary measures to scale down the soil erosion [16], rate of changes, and protect the land cover resources sustainably.

The main objective of this article is to review the actual literature on LULC in Ethiopian basins, to point out what are the existing situations and the research gap that should be addressed in the future.

\section{Case Study: Ethiopia}

Ethiopia is located in the north-eastern part of the African continent, in the so-called Horn of Africa, which lies between $3^{\circ}$ and $18^{\circ}$ north latitude, $33^{\circ}$ and $48^{\circ}$ east longitude, within the tropics (Figure 1). The total area of the country is $1,119,683 \mathrm{~km}^{2}$, while the area occupied by waterbodies is $7,444 \mathrm{~km}^{2}$ [26]. Ethiopia is a country where about more than 80 million people, containing $50.46 \%$ male; the country is grappling with all sorts of natural and manmade problems such as famine, environmental degradation, erratic rainfalls, the prevalence of malaria and HIV / AIDS, poor but improving governance, and widespread poverty. About $84 \%$ of the people live in rural areas, assuring their livelihoods with subsistence agriculture, which is a sector nowadays suffering from the lack of essential inputs and a very variable rainfall pattern. Poverty is more than common in Ethiopia, though slightly declining over time [12].

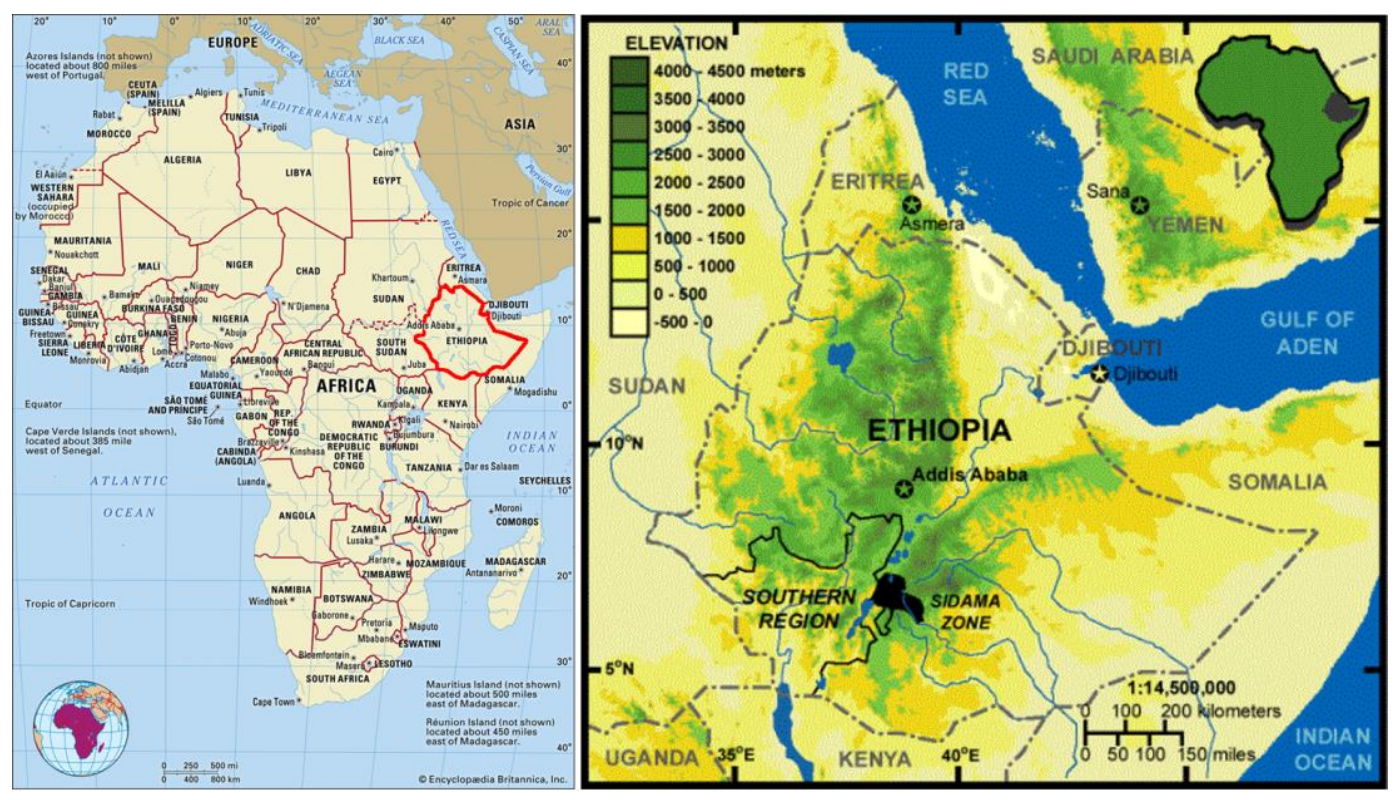

Figure 1. Maps of Africa (on the left) and Ethiopia (on the right).

In terms of geography, the prominent features of Ethiopia are the extensive high lands, surging plateaus, and deep river canyons, and the Great East African Rift System, dividing the country into the central/western part, mostly mountainous, and the southern 
highlands, which are surrounded by lowlands [27]. As indicated by Tefera [12], about $45 \%$ of the country is highland, with an average altitude greater than $1500 \mathrm{~m}$ and peaks of around $4000 \mathrm{~m}$, in which about $88 \%$ of the country's population is located. Overpopulation, extensive croplands, and frequent incision by ravines and gullies characterise the highlands. On the basis of altitude, its influence on temperature, and rainfall, Ethiopia is traditionally classified into four broad agro-climatic zones. These are termed wurch (cold moist), dega (cool humid), woina dega (semi humid), and qolla (arid and semiarid). The wurch region encompasses all areas located around $3200 \mathrm{~m}$ above the mean sea level, with an average annual rainfall of over $22 \mathrm{~mm}$. The dega zone consists of areas with altitudes and an average annual rainfall ranging from 2400 to $3200 \mathrm{~m}$, and 1200 to $2200 \mathrm{~mm}$, respectively. The woina dega zone covers areas within the altitudinal range of 1500 to $2400 \mathrm{~m}$, having an average annual rainfall of 800 to $1200 \mathrm{~mm}$. The qolla zone refers to areas lying below the altitude of $1500 \mathrm{~m}$, where the average annual rainfall is around $800 \mathrm{~mm}$ [12]. In addition to these four regions, the Ethiopian physical environment can further be classified into eleven more detailed groups, still depending on average altitude and annual rainfall: bereha (namely, desert), dry qolla, moist qolla, wet qolla, moist woina dega, wet-woina dega, moist dega, wet dega, moist wurch, wet wurch, and high wurch.

The Ethiopian economy is among the most vulnerable in sub-Saharan Africa, and it is heavily dependent on the agricultural sector, which has suffered from the recurrent droughts that are reflected in extreme fluctuations of outputs. For example, agricultural production has been growing by about $2.3 \%$ during the period 1980-2000, while the population was growing at an average rate of $2.9 \%$ per year, leading to a decline in per capita agricultural production by about $0.6 \%$ per year [15]. According to this report, the percentage of people in Ethiopia who were absolutely poor in the year 2001 was around $44 \%$, but the level of poverty shows significant variation among rural, urban areas and across regional states. In this country, the income distribution seems to be more unequally distributed in rural and urban areas, compared to other sub-Saharan African regions. To tackle this situation, in recent times, the Ethiopian Ministry of Agriculture and Rural Development (MoARD) announced one of the most detailed agro-ecological arrangements of the country by taking also soil moisture regimes into account, in addition to altitude and temperature.

\section{Methodology}

The present work is based on a review conducted on peer-reviewed articles published in the last 10 years, from 2011 to 2020, which were focused on the issue of land use land cover change in Ethiopian basins, focusing on nonurban environments. The search was based on the exact phrase of 'land use land cover changes in Ethiopia' in the Web of Google scholars, which searches within each article's title, abstract, keywords, years of publication, and 'keywords plus', a series of additional relevant keywords selected by well-known databases such as Web of Science, Scopus, and Google Scholars. Based on these criteria, 17 articles were selected and systematically reviewed to find out the strength and the research gaps in the study of LULCC in Ethiopian watersheds (Table 1).

Table 1. Summary of the revised literature.

\begin{tabular}{ccc}
\hline Article Num. & Authors & Title \\
\hline 1 & Ayana, A.A.; Kositsakulchai, E. & $\begin{array}{c}\text { Land Use Change Analysis Using Remote Sensing } \\
\text { and Markov Modelling in Fincha } \\
\text { Watershed, Ethiopia }\end{array}$ \\
\hline 2 & Dibaba, W.T.; Demissie, T.A.; Miege, K. & $\begin{array}{c}\text { Drivers and Implications of Land Use/Land Cover } \\
\text { Dynamics in Finchaa Catchment, } \\
\text { North-western Ethiopia }\end{array}$ \\
\hline 3 & $\begin{array}{c}\text { Ayana, A.B.; Edossa, D.C.; } \\
\text { Kositsakulchai, E. }\end{array}$ & $\begin{array}{c}\text { Modelling the Effects of Land Use Change and } \\
\text { Management Practices on Runoff and Sediment } \\
\text { Yields in Fincha Watershed, Blue Nile }\end{array}$ \\
\hline
\end{tabular}


Table 1. Cont.

\begin{tabular}{|c|c|c|c|}
\hline Article Num. & Authors & Title & Year \\
\hline 4 & $\begin{array}{l}\text { Betrua, T.; Tolera, M.; Sahleb. K.; } \\
\text { Kassac, H. }\end{array}$ & $\begin{array}{c}\text { Trends and Drivers of Land Use/Land Cover } \\
\text { Change in Western Ethiopia }\end{array}$ & 2019 \\
\hline 5 & $\begin{array}{l}\text { Mariye, M.; Mariyo, M.; Changming, Y.; } \\
\text { Teffera, Z.L.; Weldegebrial, B. }\end{array}$ & $\begin{array}{l}\text { Effects of Land Use and Land Cover Change on Soil } \\
\text { Erosion Potential in Berhe District: A Case Study of } \\
\text { Legedadi Watershed, Ethiopia }\end{array}$ & 2020 \\
\hline 6 & Biazina, B.; Sterk, G. & $\begin{array}{c}\text { Drought Vulnerability Drives Land Use and Land } \\
\text { Cover Changes in the Rift Valley Dry Lands } \\
\text { of Ethiopia }\end{array}$ & 2012 \\
\hline 7 & Hailua, A.; Mammo, S.; Kidane, M. & $\begin{array}{c}\text { Dynamics of Land Use, Land Cover Change Trend } \\
\text { and Its Drivers in Jimma Geneti District, } \\
\text { Western Ethiopia }\end{array}$ & 2020 \\
\hline 8 & Gebreslassie, H. & $\begin{array}{l}\text { Land Use-Land Cover Dynamics of Huluka } \\
\text { Watershed, Central Rift Valley, Ethiopia }\end{array}$ & 2014 \\
\hline 9 & Tolessa, T.; Senbeta, F.; Kidane, M. & $\begin{array}{c}\text { The Impact of Land Use/Land Cover Change on } \\
\text { Ecosystem Services in the Central Highlands } \\
\text { of Ethiopia }\end{array}$ & 2017 \\
\hline 10 & $\begin{array}{l}\text { Alemu, B.; Garedew, E.; Eshetu, Z.; } \\
\text { Kassa, H. }\end{array}$ & $\begin{array}{c}\text { Land Use and Land Cover Changes and Associated } \\
\text { Driving Forces in North-western Lowlands } \\
\text { of Ethiopia }\end{array}$ & 2015 \\
\hline 11 & $\begin{array}{l}\text { Fisseha, G.; Gebrekidan, H.; Kibret, K.; } \\
\text { Yitaferu, B.; Bedadi, B. }\end{array}$ & $\begin{array}{l}\text { Analysis of Land Use/Land Cover Changes in the } \\
\text { Debre-Mewi Watershed at the Upper Catchment of } \\
\text { the Blue Nile Basin, Northwest Ethiopia }\end{array}$ & 2011 \\
\hline 12 & Mussa, M.; Teka, H.; Mesfin, Y. & $\begin{array}{c}\text { Land Use/Cover Change Analysis and Local } \\
\text { Community Perception towards Land Cover Change } \\
\text { in the Lowland of Bale Rangelands, } \\
\text { Southeast Ethiopia }\end{array}$ & 2017 \\
\hline 13 & Alemayehu, F.; Tolera, M.; Tesfaye, G. & $\begin{array}{l}\text { Land Use Land Cover Change Trend and Its Drivers } \\
\text { in Somodo Watershed Southwestern, Ethiopia }\end{array}$ & 2019 \\
\hline 14 & $\begin{array}{l}\text { Tolessa, T.; Dechassa, C.; Simane, B.; } \\
\text { Alamerew, B.; Kidane, M. }\end{array}$ & $\begin{array}{c}\text { Land Use/Land Cover Dynamics in Response to } \\
\text { Various Driving Forces in Didessa } \\
\text { Sub-Basin, Ethiopia }\end{array}$ & 2020 \\
\hline 15 & Tefera, M.M. & $\begin{array}{l}\text { Land Use/Land Cover Dynamics in Nonno District, } \\
\text { Central Ethiopia }\end{array}$ & 2011 \\
\hline 16 & Dinka, M.O.; Klik, A. & $\begin{array}{l}\text { Effect of Land Use-Land Cover Change on the } \\
\text { Regimes of Surface Runoff-The Case of Lake } \\
\text { Basaka Catchment (Ethiopia) }\end{array}$ & 2019 \\
\hline 17 & Othow, O.O.; Gebre, S.L.; Gemeda, D.O. & $\begin{array}{c}\text { Analysing the Rate of Land Use and Land Cover } \\
\text { Change and Determining the Causes of Forest Cover } \\
\text { Change in Gog District, Gambella Regional } \\
\text { State, Ethiopia }\end{array}$ & 2017 \\
\hline 18 & $\begin{array}{l}\text { Berihu, L.B.; Tsunekawa, A.; } \\
\text { Haregeweyn, N.; Meshesha, B.T.; Adgo, } \\
\text { E.; Tsubo, M.; Masunaga, T.; Fenta, A.A.; } \\
\text { Sultan, D.; Yibeltal, M. }\end{array}$ & $\begin{array}{l}\text { Exploring Land Use/Land Cover Changes, Drivers, } \\
\text { and Their Implications in Contrasting } \\
\text { Agro-Ecological Environments Of Ethiopia }\end{array}$ & 2019 \\
\hline 19 & $\begin{array}{c}\text { Gashaw, T.; Tulu, T.; Argaw, M.; Worqlul, } \\
\text { A.W. }\end{array}$ & $\begin{array}{l}\text { Evaluation and Prediction of Land Use/Land Cover } \\
\text { Changes in the Andassa Watershed, Blue Nile } \\
\text { Basin, Ethiopia }\end{array}$ & 2017 \\
\hline 20 & Andualem, T.G.; Gebremariam, B. & $\begin{array}{l}\text { Impact of Land Use Land Cover Change on Stream } \\
\text { Flow and Sediment Yield: A Case Study of Gilgel } \\
\text { Abay Watershed, Lake Tana Sub-Basin, Ethiopia }\end{array}$ & \\
\hline 21 & Getachew, H.E.; Melesse, A.M. & $\begin{array}{c}\text { The Impact of Land Use Change on the Hydrology } \\
\text { of the Angereb Watershed, Ethiopia }\end{array}$ & 2012 \\
\hline
\end{tabular}


Table 1. Cont.

\begin{tabular}{|c|c|c|c|}
\hline Article Num. & Authors & Title & Year \\
\hline 22 & Meshesha, T.W.; Tripathi, S.K.; Khare, D. & $\begin{array}{c}\text { Analyses of Land Use and Land Cover Change } \\
\text { Dynamics Using GIS and Remote Sensing During } \\
1984 \text { and } 2015 \text { in the Beressa Watershed Northern } \\
\text { Central Highland of Ethiopia }\end{array}$ & 2016 \\
\hline 23 & Miheretu, B.A,; Yimer, A.A. & $\begin{array}{l}\text { Land Use/Land Cover Changes and Their } \\
\text { Environmental Implications in the Gelana } \\
\text { Sub-Watershed of Northern Highlands of Ethiopia }\end{array}$ & \\
\hline 24 & Molla, M.B. & $\begin{array}{c}\text { Land Use/Land Cover Dynamics in the Central Rift } \\
\text { Valley Region of Ethiopia: Case of Arsi } \\
\text { Negele District }\end{array}$ & 2015 \\
\hline 25 & Sewnet, A.; Abebe, G. & $\begin{array}{c}\text { Land Use and Land Cover Change and Implication } \\
\text { to Watershed Degradation by Using GIS and Remote } \\
\text { Sensing in the Koga Watershed, } \\
\text { North-western Ethiopia }\end{array}$ & 2018 \\
\hline
\end{tabular}

In terms of geographical distribution, the considered articles cover a large part of the country, spanning different agro-climatic zones (Figure 2). Since no articles that referred to LULCCs in the eastern part were found, the outcomes summarised in the present study can be considered representative of a general trend of LULCCs in Ethiopia, except for the Ogaden Region.

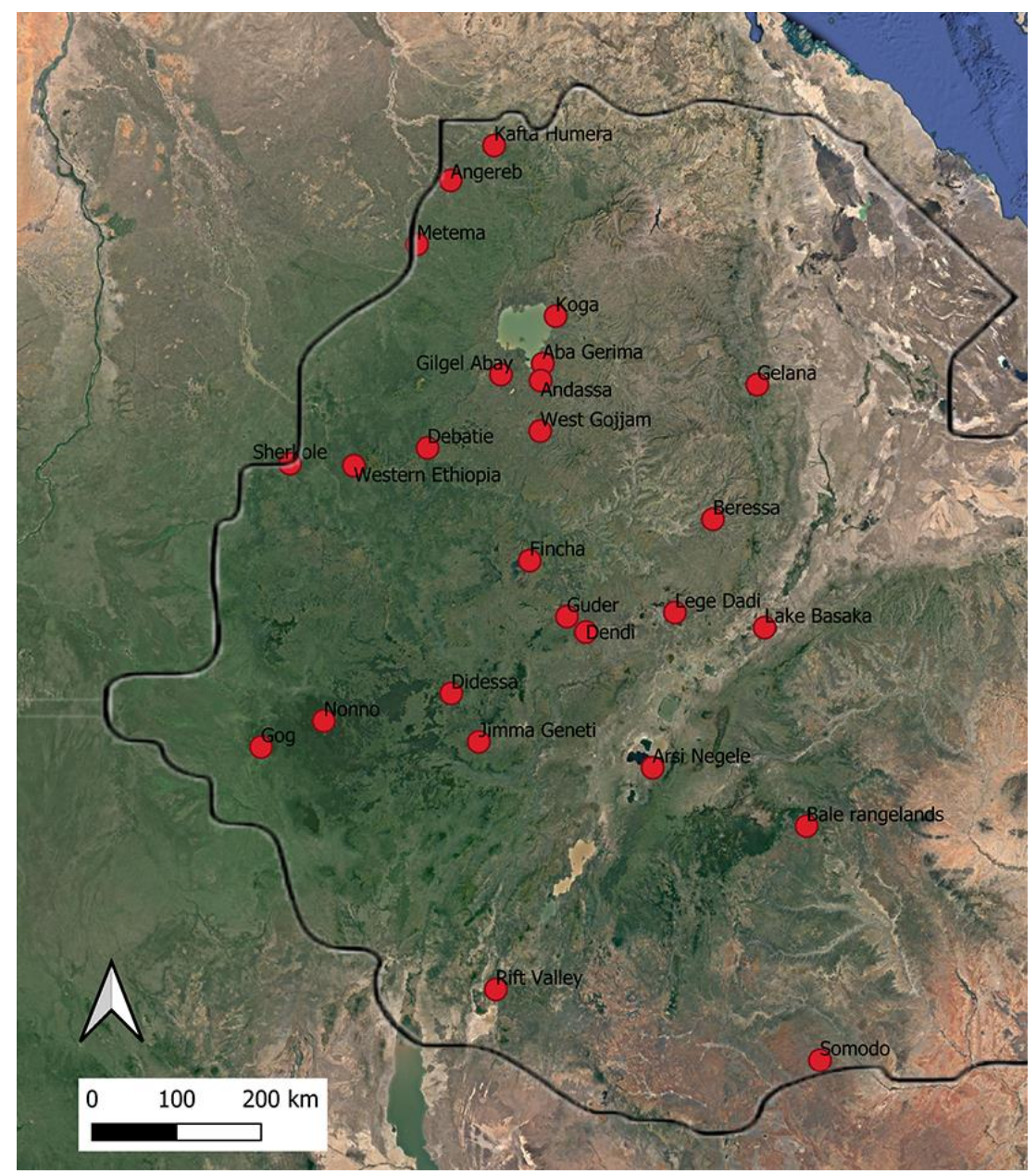

Figure 2. Main locations of the studies. Some reviewed articles referred to the same watershed, hence are here reported only once. The Ethiopian borders are indicated with a black line. 
Due to not being yet standardised, the LULC classification method is highly subjective and can change from one study to the other (Table 2).

Table 2. Characteristics of the study area for the selected case studies in Ethiopia.

\begin{tabular}{|c|c|c|c|c|c|c|}
\hline $\begin{array}{l}\text { Article } \\
\text { Num. }\end{array}$ & Study Site & $\begin{array}{l}\text { Ethiopian } \\
\text { Region }\end{array}$ & Coordinates & Study Period & Model & Method \\
\hline 1 & $\begin{array}{c}\text { Fincha } \\
\text { watershed }\end{array}$ & Oromiyaa & $\begin{array}{l}\text { between } 9^{\circ} 10^{\prime} 05^{\prime \prime}-10^{\circ} 00^{\prime} 59^{\prime \prime} \\
N \text { and } 37^{\circ} 00^{\prime} 16^{\prime \prime}-37^{\circ} 33^{\prime} 20^{\prime \prime} \mathrm{E}\end{array}$ & 1985-2005 & $\begin{array}{l}\text { ERDAS } \\
\text { Imagine } \\
\text { software }\end{array}$ & $\begin{array}{l}\text { supervised maximum } \\
\text { likelihood method }\end{array}$ \\
\hline 2 & $\begin{array}{c}\text { Fincha } \\
\text { watershed }\end{array}$ & Oromiyaa & $\begin{array}{l}\text { between } 9^{\circ} 10^{\prime} 05^{\prime \prime}-10^{\circ} 00^{\prime} 59^{\prime \prime} \\
\mathrm{N} \text { and } 37^{\circ} 00^{\prime} 16^{\prime \prime}-37^{\circ} 33^{\prime} 20^{\prime \prime} \mathrm{E}\end{array}$ & 1987-2017 & ArcGIS & $\begin{array}{l}\text { supervised maximum } \\
\text { likelihood method }\end{array}$ \\
\hline 3 & $\begin{array}{c}\text { Fincha } \\
\text { watershed }\end{array}$ & Oromiyaa & $\begin{array}{l}\text { between } 9^{\circ} 10^{\prime} 05^{\prime \prime}-10^{\circ} 00^{\prime} 59^{\prime \prime} \\
N \text { and } 37^{\circ} 00^{\prime} 16^{\prime \prime}-37^{\circ} 33^{\prime} 20^{\prime \prime} \mathrm{E}\end{array}$ & 2005 & $\begin{array}{l}\text { ERDAS } \\
\text { Imagine } \\
\text { software }\end{array}$ & $\begin{array}{l}\text { combination of } \\
\text { supervised classification } \\
\text { based on the minimum } \\
\text { distance algorithm } \\
\text { method }\end{array}$ \\
\hline 4 & Asosa zone & $\begin{array}{l}\text { Benishangul } \\
\text { Gumuz }\end{array}$ & $\begin{array}{c}\text { between } 9^{\circ} 33^{\prime}-10^{\circ} 54^{\prime} \mathrm{N} \text { and } \\
34^{\circ} 08^{\prime}-35^{\circ} 21^{\prime} \mathrm{E}\end{array}$ & 1978-2016 & not described & $\begin{array}{l}\text { hybrid supervised } \\
\text { classified and intensive } \\
\text { on-screen digitizing } \\
\text { (visual image } \\
\text { interpretation) method }\end{array}$ \\
\hline 5 & $\begin{array}{c}\text { Legedadi } \\
\text { watershed }\end{array}$ & Oromiyaa & $\begin{array}{l}\text { between } 9^{\circ} 01^{\prime}-9^{\circ} 13^{\prime} \mathrm{N} \text { and } \\
\quad 38^{\circ} 60^{\prime}-39^{\circ} 07^{\prime} \mathrm{E}\end{array}$ & 1985-2013 & $\begin{array}{c}\text { ERDAS } \\
\text { Imagine } 9.2\end{array}$ & $\begin{array}{l}\text { supervised maximum } \\
\text { likelihood method }\end{array}$ \\
\hline 6 & Rift Valley & Oromiyaa & & 1965-2010 & $\begin{array}{l}\text { ERDAS } \\
\text { Imagine and } \\
\text { ArcGIS }\end{array}$ & $\begin{array}{l}\text { supervised maximum } \\
\text { likelihood method }\end{array}$ \\
\hline 7 & $\begin{array}{l}\text { Jimma } \\
\text { Geneti } \\
\text { district }\end{array}$ & Oromiyaa & & $1973-2019$ & $\begin{array}{c}\text { ERDAS } \\
\text { imagine } 14.1 \\
\text { and ArcGIS } \\
10.3\end{array}$ & $\begin{array}{l}\text { supervised maximum } \\
\text { likelihood method }\end{array}$ \\
\hline 8 & $\begin{array}{c}\text { Huluka } \\
\text { watershed }\end{array}$ & Oromiyaa & $\begin{array}{l}\text { between } 7^{\circ} 16.4^{\prime}-7^{\circ} 30.7^{\prime} \mathrm{N} \text { and } \\
\quad 38^{\circ} 47.7^{\prime}-38^{\circ} 44.3^{\prime} \mathrm{E}\end{array}$ & 1973-2009 & $\begin{array}{l}\text { ERDAS } \\
\text { Imagine }\end{array}$ & $\begin{array}{c}\text { combination of } \\
\text { unsupervised and } \\
\text { supervised maximum } \\
\text { likelihood method }\end{array}$ \\
\hline 9 & $\begin{array}{l}\text { Chillimo } \\
\text { Forest }\end{array}$ & Oromiyaa & $38^{\circ} 10^{\prime} \mathrm{E}-9^{\circ} 05^{\prime} \mathrm{N}$ & 1973-2015 & $\begin{array}{l}\text { ERDAS } \\
\text { imagine. } 10\end{array}$ & $\begin{array}{l}\text { supervised maximum } \\
\text { likelihood method }\end{array}$ \\
\hline 10 & $\begin{array}{l}\text { Kafta } \\
\text { Humera, } \\
\text { Metema } \\
\text { and } \\
\text { Shorkole }\end{array}$ & $\begin{array}{l}\text { Tigray, Amhara, } \\
\text { and Benis- } \\
\text { hangulGumuz }\end{array}$ & $\begin{array}{c}\text { between } 13^{\circ} 39^{\prime} 46.5 \\
"-14^{\circ} 26^{\prime} 34.9^{\prime \prime} \mathrm{N} \text { and } 36^{\circ} 27^{\prime} 4.7 \\
"-37^{\circ} 33^{\prime} 7.1^{\prime \prime} \mathrm{E} \text {; between } \\
12^{\circ} 17^{\prime} 33.63^{\prime \prime}-13^{\circ} 5^{\prime} 52.52^{\prime \prime} \mathrm{N} \\
\text { and } \\
35^{\circ} 45^{\prime} 21.34^{\prime \prime}-36^{\circ} 45^{\prime} 31.31^{\prime \prime} \mathrm{E} ; \\
\text { between } 10^{\circ} 26^{\prime} 18.98 \\
\prime-11^{\circ} 14^{\prime} 25.65^{\prime \prime} \mathrm{N} \text { and } \\
34^{\circ} 45^{\prime} 21.33^{\prime \prime}-35^{\circ} 45^{\prime} 31.30^{\prime \prime} \mathrm{E} ;\end{array}$ & 1985-2010 & ArcGIS & $\begin{array}{c}\text { combination of } \\
\text { unsupervised and } \\
\text { supervised maximum } \\
\text { likelihood method }\end{array}$ \\
\hline 11 & $\begin{array}{c}\text { Debre- } \\
\text { Mewi } \\
\text { watershed }\end{array}$ & Amhara & $\begin{array}{l}\text { between } 11^{\circ} 20^{\prime}-11^{\circ} 21^{\prime} \mathrm{N} \text { and } \\
\qquad 37^{\circ} 24^{\prime}-37^{\circ} 25^{\prime} \mathrm{E}\end{array}$ & 1957-2008 & $\begin{array}{l}\text { ArcGIS } 9.2 \\
\text { software }\end{array}$ & $\begin{array}{l}\text { visual interpretation and } \\
\text { digitised based on false- } \\
\text { colour composites method }\end{array}$ \\
\hline 12 & $\begin{array}{l}\text { Raitu } \\
\text { district }\end{array}$ & Oromiyaa & $\begin{array}{l}\text { between } 6^{\circ} 20^{\prime} 0 "-7^{\circ} 25^{\prime} 0 " \mathrm{~N} \\
\text { and } 41^{\circ} 30^{\prime} 00^{\prime \prime}-42^{\circ} 00^{\prime} 00^{\prime \prime} \mathrm{E}\end{array}$ & 1986-2016 & $\begin{array}{c}\text { ERDAS } \\
\text { Imagine and } \\
\text { ArcGIS } 10.5\end{array}$ & $\begin{array}{c}\text { combination of } \\
\text { unsupervised and } \\
\text { supervised classification } \\
\text { methods }\end{array}$ \\
\hline 13 & $\begin{array}{c}\text { Somodo } \\
\text { watershed }\end{array}$ & Oromiyaa & $\begin{array}{l}\text { between } 7^{\circ} 46^{\prime} 00^{\prime \prime}-7^{\circ} 47^{\prime} 00 " \\
\mathrm{~N} \text { and } 36^{\circ} 47^{\prime} 00^{\prime \prime}-36^{\circ} 48^{\prime} 00^{\prime \prime} \mathrm{E}\end{array}$ & 1985-2017 & $\begin{array}{l}\text { ERDAS } \\
\text { Imagine }\end{array}$ & $\begin{array}{l}\text { both unsupervised and } \\
\text { maximum likelihood } \\
\text { supervised method }\end{array}$ \\
\hline 14 & $\begin{array}{l}\text { Didessa } \\
\text { sub-basin }\end{array}$ & Oromiyaa & & 1974-2014 & $\begin{array}{c}\text { ERDAS } \\
\text { IMAGINE } 2010 \\
\text { and ArcGIS } \\
10.5\end{array}$ & $\begin{array}{l}\text { both unsupervised and } \\
\text { maximum likelihood } \\
\text { supervised method }\end{array}$ \\
\hline 15 & $\begin{array}{l}\text { Nonno } \\
\text { district }\end{array}$ & Oromiyaa & $\begin{array}{l}\text { between } 2^{\circ} 54^{\prime}-15^{\circ} 18^{\prime} \mathrm{N} \text { and } \\
32^{\circ} 42^{\prime}-48^{\circ} 18^{\prime} \mathrm{E}\end{array}$ & 1984-2007 & $\begin{array}{l}\text { ENVI } 4.3 \text { and } \\
\text { ArcGIS } 9.3\end{array}$ & supervised classification \\
\hline
\end{tabular}


Table 2. Cont.

\begin{tabular}{|c|c|c|c|c|c|c|}
\hline $\begin{array}{l}\text { Article } \\
\text { Num. }\end{array}$ & Study Site & $\begin{array}{l}\text { Ethiopian } \\
\text { Region }\end{array}$ & Coordinates & Study Period & Model & Method \\
\hline 16 & $\begin{array}{c}\text { Lake } \\
\text { Basaka } \\
\text { catchment }\end{array}$ & Oromiyaa & & 1973-2015 & $\begin{array}{l}\text { ERDAS } \\
\text { Imagine }\end{array}$ & $\begin{array}{l}\text { unsupervised and } \\
\text { maximum likelihood } \\
\text { supervised method }\end{array}$ \\
\hline 17 & Gog district & Gambella & $\begin{array}{c}\text { between } \\
7^{\circ} 27^{\prime} 38^{\prime \prime}-8^{\circ} 18^{\prime} 57^{\prime \prime} \mathrm{N} \text { and } \\
34^{\circ} 14^{\prime} 59^{\prime \prime}-35^{\circ} 33^{\prime} 49^{\prime \prime} \mathrm{E}\end{array}$ & 1990-2017 & $\begin{array}{l}\text { ERDAS } \\
\text { Imagine }\end{array}$ & $\begin{array}{l}\text { maximum likelihood } \\
\text { supervised method }\end{array}$ \\
\hline 18 & $\begin{array}{l}\text { Guder, Aba } \\
\text { Gerima and } \\
\text { Debatie } \\
\text { watersheds }\end{array}$ & Oromiyaa & & 1982-2017 & ArcGIS 10.4 & $\begin{array}{l}\text { visual interpretation } \\
\text { on-screen digitisation } \\
\text { technique }\end{array}$ \\
\hline 19 & $\begin{array}{c}\text { Andassa } \\
\text { watershed }\end{array}$ & Amhara & $\begin{array}{l}\text { between } 11^{\circ} 08^{\prime}-11^{\circ} 32^{\prime} \mathrm{N} \text { and } \\
37^{\circ} 16^{\prime}-37^{\circ} 32^{\prime} \mathrm{E}\end{array}$ & 1985-2045 & $\begin{array}{c}\text { ERDAS } \\
\text { Imagine } 2014 \\
\text { and ArcGIS } \\
10.3\end{array}$ & $\begin{array}{l}\text { both unsupervised and } \\
\text { supervised classification } \\
\text { methods }\end{array}$ \\
\hline 20 & $\begin{array}{l}\text { Gilgel Abay } \\
\text { watershed }\end{array}$ & Amhara & $\begin{array}{l}\text { between } 10^{\circ} 56^{\prime}-11^{\circ} 51^{\prime} \mathrm{N} \text { and } \\
\qquad 36^{\circ} 44^{\prime}-37^{\circ} 23^{\prime} \mathrm{E}\end{array}$ & 1986-2011 & $\begin{array}{l}\text { ERDAS } \\
\text { Imagine and } \\
\text { ArcGIS }\end{array}$ & not mentioned \\
\hline 21 & $\begin{array}{c}\text { Angereb } \\
\text { watershed }\end{array}$ & Amhara & $\begin{array}{c}\text { between } \\
12^{\circ} 36^{\prime} 22^{\prime \prime}-12^{\circ} 43^{\prime} 34.8^{\prime \prime} \mathrm{N} \text { and } \\
37^{\circ} 25^{\prime} 2^{\prime \prime}-37^{\circ} 30^{\prime} 28^{\prime \prime} \mathrm{E}\end{array}$ & 1985-2011 & $\begin{array}{l}\text { ERDAS } \\
\text { Imagine and } \\
\text { ArcGIS }\end{array}$ & $\begin{array}{l}\text { maximum likelihood } \\
\text { supervised method }\end{array}$ \\
\hline 22 & Beressawatershed & Amhara & $\begin{array}{l}\text { between } 9^{\circ} 40^{\prime}-9^{\circ} 41^{\prime} \text { and } \\
39^{\circ} 37^{\prime}-39^{\circ} 32^{\prime} \mathrm{E}\end{array}$ & 1984-2015 & $\begin{array}{l}\text { ArcGIS10.2.2 } \\
\text { and ERDAS } \\
\text { Imagine14 }\end{array}$ & $\begin{array}{l}\text { maximum likelihood } \\
\text { supervised method }\end{array}$ \\
\hline 23 & $\begin{array}{l}\text { Gelana } \\
\text { sub-basin }\end{array}$ & Amhara & $\begin{array}{c}\text { between } \\
11^{\circ} 34^{\prime} 44^{\prime \prime}-11^{\circ} 45^{\prime} 4^{\prime \prime} \mathrm{N} \text { and } \\
39^{\circ} 34^{\prime} 11^{\prime \prime}-39^{\circ} 45^{\prime} 2^{\prime \prime} \mathrm{E}\end{array}$ & 1964-1984 & $\begin{array}{c}\text { ERDAS } \\
\text { Imagine9.1 }\end{array}$ & $\begin{array}{l}\text { maximum likelihood } \\
\text { supervised method }\end{array}$ \\
\hline 24 & $\begin{array}{l}\text { Arsi Negele } \\
\text { district }\end{array}$ & Oromiyaa & $\begin{array}{l}\text { between } 7^{\circ} 09^{\prime}-7^{\circ} 41^{\prime} \mathrm{N} \text { and } \\
38^{\circ} 25^{\prime}-38^{\circ} 54^{\prime} \mathrm{E}\end{array}$ & 1973-2010 & $\begin{array}{l}\text { ERDAS } \\
\text { Imagine } 8.7 \text { and } \\
\text { ArcGIS }\end{array}$ & Not mentioned \\
\hline 25 & $\begin{array}{c}\text { Koga } \\
\text { watershed }\end{array}$ & Amhara & $\begin{array}{l}\text { between } 11^{\circ} 10^{\prime}-11^{\circ} 25^{\prime} \mathrm{N} \text { and } \\
370^{\circ} 2^{\prime}-370^{\circ} 17^{\prime} \mathrm{E}\end{array}$ & 1973-2011 & $\begin{array}{l}\text { ArcGIS, IDL, } \\
\text { and ERDAS } \\
\text { Imagine }\end{array}$ & $\begin{array}{l}\text { hybrid unsupervised and } \\
\text { supervised Method }\end{array}$ \\
\hline
\end{tabular}

In the present analysis, land classes' names which may have a similar meaning or approach were considered as one. For example, the brushland class cover was considered as a shrubland class cover. Moreover, in some cases, a single class was classified as a combination of both, such as in the case of [28-30], where the settlement and agricultural land cover classes were classified together and defined as the 'settlement/agricultural' class. For such a case, we selected only the dominating class. Therefore, the agricultural class was chosen instead of the built-up/settlement one.

For those articles that did not describe the LULCCs for each class between the final and initial year, the percentage of LULCCs was as follows:

$$
L U L C C=\frac{\left(L U L C_{t 1}-L U L C_{t 0}\right)}{A} * 100
$$

where $A$ is the total area of the study region, while $t 0$ and $t 1$ are the initial and final years, respectively.

To compare the different articles, the LULCC percentages of each watershed were determined as

$$
\text { LULCC }_{W}=\frac{\text { PLCCC in P } 1+P L C C C \text { in P2 }+ \text { PLCCC in P }+\ldots+P L C C C \text { in P25 }}{\text { total number of articles in which the LULC was used }}
$$

where $W$ indicates the watershed, while PLCCC and $P$ represent the percentage of land class cover change and the article number (Table 1), respectively. 
For example, agricultural LULCs were classified in all articles except in the work of Ayana et al. [31]. Therefore, the magnitude of such LULCCs was determined depending on the 16 articles, as

$$
\frac{A g 1+A g 2+A g 4+A g 5+A g 6+A g 7+A g 8+A g 9+A g 10+\ldots+A 25}{124}
$$

where $A g$ is the agricultural land use, while the subscripts indicate the article number.

As another example, the percentage of waterbody LULCCs was calculated as follows:

$$
\frac{W b 1+W b 2+W b 5+W b 7+W b 10+W b 16+W b 17+W b 20+W b 21+W b 22+W b 25}{11}
$$

where $W b$ is the waterbody land use. From this, it can be seen that the waterbody LULCCs are addressed in articles 1, 2, 5, 7, 10, 16, 17, 20, 21, 22, and 25 (see Table 1).

\section{Article Analysis}

In this section, we report briefly the main outcomes of each study (see Table 2), aiming to provide the readers with a few more details needed for critical comparison.

According to Mariye et al. [2], the maximum likelihood classification method was used to study LULC of the Lege Dadi watershed, for 1995, 1997, and 2013, by using the ERDAS Imagine 9.2 software. The study was aimed to investigate the effects of LULCC on soil erosion potential in the Berhe District, a small portion of the Lege Dadi Basin. To achieve the objective of the study, Landsat satellite images were downloaded from the United States Geological Survey (USGS) official website (earthexplorer.usgs.gov). The results of classification show six LULC classes: water body (including human-made reservoir), cultivated land, settlement, grazing land, forest (composed mainly of Eucalyptus globules plantation), and bare land. Comparing the different years, the authors observed that cultivated land, settlement, and forest increased, while a decrease was observed looking at the areas covered by water bodies, grazing land, and bare land. Besides using remote imagery, the authors of this study conducted a series of focus group discussions with farmers, development agents, cabinet members, elders, and knowledgeable community representatives to obtain further information about the long-term experience of LULC practices in the watersheds. In their report, the settlement area and cultivated land were increased significantly, whereas grazing land and bare land classes were reduced, confirming what was retrieved from satellite data.

Similarly, in [29], a maximum likelihood classification method was used in combination with a geographic information system (GIS) to study the drought vulnerability drives of LULCCs in the Rift Valley drylands of Ethiopia using aerial photographs, satellite imagery, rainfall, and ground measured data. Specifically, aerial and satellite images refer to 1965, 1986, and 2000, while ground-based measurements were taken in 2010. The input data, such as aerial photographs and satellite images, were obtained from the Ethiopian Mapping Authority and Global Land Cover Facility (glcf.umd.edu/data/landsat), respectively. Additionally, in this case, focused group discussions with selected stakeholders and semi-structured interviews with key informants, as well as questionnaires, were considered as a support methodology to assess LULCCs in the area. The report shows five LULC classes, such as dense acacia woodland, scattered acacia with grass undergrowth, grassland, cultivated land, and bare lands. Both dense acacia vegetation and scattered acacia were consistently decreased from 1965 to 2010; grassland cover was increased from 1965 to 2000 years and slightly decreased from 2000 to 2010 years; bare land was increased from 1965 to 1986 and then decreased from 1986 to 2010 years. The cultivated land was increased from 1986 to 2010 years. From this analysis, it is clear that agriculture is becoming the predominant LULC class in the basin.

Gebreslassie [16] studied the LULC dynamics of the Huluka watershed, Central Rift Valley, Ethiopia, from 1973 to 2009. In this research, both supervised and unsupervised classification was used to classify LULC via the ERDAS Imagine 8.4 software. During the study, 
key informant interviews, focal group discussions, and field data collection were combined to validate the results. The finding shows six LULC classes, namely, cultivated land, woodland, open land, grassland, shrubland, continuous NF, fragmented NH, and plantation forest. Of these LULC classes, only cultivated and open lands had shown continuous and progressive expansion, mainly at the expense of grass, shrub, and forest lands. In detail, the $25 \%$ and $0 \%$ of cultivated and open land of the watershed in 1973 expanded to $84 \%$ and $4 \%$ in 2009 , respectively, while the $29 \%, 18 \%$, and $22 \%$ of grass, shrub, and forest land of the watershed in 1973 decreased to $3.5 \%, 4 \%$ and $1.5 \%$ in 2009 , respectively.

To evaluate the trends and drivers of LULC in western Ethiopia, Betru et al. [28] classified the region into four classes (forest, agriculture, shrub/grass, and settlement), comparing the years 1978, 1986, 1991, 1999, 2010, 2013, and 2016. They adopted a hybrid method, combining the outputs of supervised classified and intensive on-screen digitizing (visual image interpretation) techniques to produce LULC maps. To determine LULCCs, multi-sensor and multitemporal Landsat images were accessed freely from the USGS website. To validate the results, key informant interviews and focal group discussion was conducted to collect historical information of the last decades. The report shows that $74 \%$ of forest was maintained, while the remaining was changed to shrub/grassland (21\%) and agriculture (5\%) to 1986 and 1991; nearly 95\% of the forest gain in this period was from shrub/grassland. Between 1978 and 1986, most of the forest was degraded to shrub/grasslands for the need of construction materials, fuelwood, and charcoal; similar to the period from 1986 to 1991, 32\% of forest was lost from 1991 to 2010, and the conversion during this period was to shrub/grass and agriculture. Further, $51.7 \%$ and $44.7 \%$ of the forest land was converted to agriculture and shrub/grasslands, respectively, due to the large expansion of commercial agricultural practice between 2010 and 2016. In the same period, also $25 \%$ of the forest land was recovered from shrub/grassland.

In [30], the authors focused on the Fincha watershed. The basin was classified into agricultural land, forest land, grazing land, waterbody, swamp, and shrubland classes for the years 1985, 1995, and 2005. The goal of this work was to evaluate LULCC combining remote sensing and Markov Modelling by using freely available Landsat data. The ERDAS Imagine software and a number of methodologies such as supervised maximum likelihood classification, LULC detections, and spatial matrix analysis were adopted to evaluate LULCCs for the 20-year study period, analysing separately the decades 1985-1995 and 1995-2005. The finding shows that agricultural land and water bodies increased in the area by around $54 \%$ and $93 \%$, respectively, while great losses were observed in the case of forest land, grazing land, swamp area, and shrubland, by 51\%, 31\%, 51\%, and 25\%, respectively.

Looking at the same basin, Dibaba et al. [18] applied a supervised classification with the maximum likelihood classifier in ArcGIS to classify the land classes in the years 1987, 200, and 2017, combining Landsat images, digital elevation model, and field data. The aim of this study was to compare the changes between the different years, in addition to understanding their drivers and implications. The research pointed out that, during the last 30 years, agricultural land, commercial farm, built-up and waterbody classes increased by $16 \%, 5 \%, 1.7 \%$, and $1.7 \%$, respectively, while forest land, rangeland, grazing land, and swampy areas decreased by $12 \%, 8 \%, 3 \%$, and $1 \%$, respectively. To support the research outcomes, the authors carried out key informant interviews, focal group discussions, and field data collection, focusing on socioeconomic aspects.

Likewise, in [31], Ayana et al. classified the LULC of the Fincha watershed for the year 2005, using Landsat ETM+ images, to model the effects of LULCCs and management practices on the runoff and sediment yields in the Fincha watershed. The authors combined supervised classification based on the minimum distance algorithm method, a digital elevation model, LULC data, soil information, and weather data. Their results show six classes: agricultural land, forest, grazing land, waterbody, swamp area, and shrubland. In accordance with evidence pointed out by other authors ([18,30]), more than half of the watershed was covered by agricultural land and the remaining was covered, in decreasing order, by waterbody, grazing land, forest, shrubland, and swamp. 
Hailu et al. [32] studied the dynamics and drivers of LULCC in the Jimma Geneti District, western Ethiopia, from 1973 to 2019, using satellite images from the USGS website. A supervised maximum likelihood classification method was adopted to classify LULC change within the period, while key informant interviews and focal group discussions were carried out to validate the results. In total, the authors classified six LULC classes: bare land, cultivated land, forest, settlement area, waterbody, and wetland. During the study period, cultivated land, settlement area, and water bodies increased, whereas forest land, bare land, and wetlands decreased.

In his work, Tolessa et al. [33] studied the impact of LULCCs on ecosystem services in the central highlands of Ethiopia, from 1973 to 2015, by using multispectral Landsat imaginary (Landsat MSS, TM, ETM+, and Land OLS). Analysing these satellite images via the maximum likelihood classification method, they were able to classify the region into five classes (settlement, cultivated land, bare land, shrubland, and forest). The authors performed ground control points to assist the supervised image classification. The report shows the cultivated land and shrubland expanded significantly between 1973 and 2015, while the forest decreased. No significant changes were observed on both settlement area and bare land.

Alemu et al. [34] analysed the LULCC implications and drivers in the North-western Lowlands of Ethiopia during the period 1985-2010 by combining supervised and unsupervised methods of remotely sensed images. Similar to other studies, key informant interviews, group discussions, and ground control points were performed to validate the classification results. The study areas were classified into six LULC classes, namely, agricultural land, bare land and settlement, woodland, shrubland, grassland, and water body. By comparing three reference years $(1985,1995,2010)$, the authors pointed out an increment of the area covered by agriculture, bare land and settlement, grassland, and water bodies, while woodland and shrubland declined.

In [35], the authors concentrated on the Debre-Mewi watershed, which is the upper catchment of the Blue Nile Basin, in northwest Ethiopia. In this case, three reference years were observed $(1957,1982$, and 2008), and aerial photographs and multispectral Landsat satellite images were compared to assess LULCC. To validate the outcomes, information derived from key informant groups and focal group discussions, as well as field data, were collected. The report shows that the area was classified into four LULC classes: natural forest, shrub and bushland, grazing land, and cultivated and settlement land in 1957. Additional classes were added for the 1982 (Eucalyptus plantation) and 2008 (Eucalyptus plantation, rock outcrop) analyses. In fact, after the 1960s, most individual farmers started cultivating plantations around their homesteads, as a source of fuelwood, construction material, and income generation, and some of the severely degraded cultivated and grazing lands were converted to rock outcrops. For this reason, during the last decades cultivated and settlement areas increased significantly, whereas natural forest, shrub and bushland, and grazing land declined rapidly.

According to [36], a combination of unsupervised and supervised classification methods was employed to classify Landsat images of the Bale rangelands, in southeast Ethiopia, to study LULCC at the regional scale, and how the local community perceived such changes. The authors performed key informant interviews and field data collection to support and validate the results. In this case, the study area was classified into seven LULC classes: woodland, bushland, shrubby grassland, grassland, cultivated land, bare land, and settlement, using 1986, 2001, and 2016 as reference years. During these 30 years, cultivated land, settlement, bushland, and bare land expanded by $14 \%, 15 \%, 13 \%$, and $22 \%$, respectively, while woodland, grassland, and shrubby grassland declined by $34 \%, 24 \%$, and $3 \%$, respectively.

Alemayehu et al. [3] studied the trend of LULCCs in the Somodo watershed, southwestern Ethiopia, trying to address the main drivers of such changes. They applied both unsupervised and maximum likelihood supervised classification methods using ERDAS imagine 9.1. Landsat images, freely obtained from the USGS website, and key informants, 
focal group discussions, and field data techniques were combined to derive coherent information. The Somodo watershed was classified into four LULC classes: agriculture, forest, grass, and home garden agroforestry. The study addressed the changes that occurred between 1985 and 2017, pointing out that the area covered by forest and agriculture decreased by 61 ha $(13 \%)$ and 5 ha $(1 \%)$, respectively. In contrast, home garden agroforestry/settlement and grassland increased by around $50(7 \%)$ and $16(6 \%)$, respectively. The authors calculated that assuming the same existing rate of LULCCs, in 2029, agriculture and forestland are predicted to increase by 91 ha and 21 ha, respectively, while grassland and home garden agroforestry/settlement will decrease by 100 ha and 11.79 ha, respectively.

The study in [9] was conducted on LULC dynamics in the Didessa sub-basin, trying to understand the various driving forces that shaped the landscape in the period 1974-2014, looking at decadal changes. The analysis was performed via both the unsupervised and supervised classification methods, using the ERDAS Imagine 2010 classifier within the ArcGIS software. As made in similar studies, the imagery data used for land cover change were obtained freely from the USGS website, while key informant interviews and focal group discussions were carried out for better understanding the observed dynamics and validate the satellite data. In this case, the study area was classified into seven LULC classes: wetland, shrubland, settlement, grassland, forest, cultivated land, and commercial land. The authors' analysis shows that, during the four decades (1974-2014), agricultural land, settlement, and commercial land increased, while wetland, grassland, forest, and shrubland rapidly decreased.

Tefera [12] studied LULC dynamics in the Nonno District, located in central Ethiopia, for the period 1987-2007. The research combined three satellite datasets: Landsat Thematic Mapper with $30 \mathrm{~m}$ of spatial resolution (image of 1984), Landsat Enhanced Thematic Mapper Plus with $30 \mathrm{~m}$ resolution (image of 2002), and SPOT image of 2007 with $5 \mathrm{~m}$ resolution. Key informant interviews specifically made with older peoples, focal group discussions, and field data were combined to validate the satellite-derived LULCC analysis. The Nonno District was classified into woodland, shrubland, grassland, cultivated land, settlement site, and town. During the observed period, woodland and grassland decreased their extension, while shrubland, cultivated areas, and settlements expanded. In particular, woodland and farmland were the two most decreased and increased land use types in the district, respectively.

Focusing on the Lake Basaka catchment, Dinka and Klik [20] studied how LULCC affected the regimes of surface runoff during the period 1973-2015. To do that, they adopted a common methodology, processing Landsat data with the ERDAS Imagine software, and using both unsupervised and supervised classification methods. The catchment area was classified into seven classes: farmland, forest (comprising dense woods), shrubland, grassland, bushy woods (open) land, wetland, and water body. The report indicates that the Lake Basaka catchment experienced significant LULCCs: about $86 \%$ of forest coverage and $46 \%$ of grasslands were lost, and the territory was transformed to open bushy woodlands, farms, lakes, and wetlands.

To analyse the rate of LULCCs during the period 1990-2017 and determine the causes of changes in forest coverage in the Gog District, Gambella Regional State, Othow et al. [21] used the maximum likelihood technique of the supervised classification of the ERDAS Imagine 2014 software. The area was classified into six classes: water body, forest, farmland, bushland, bare land, and grassland. The authors used free thematic maps (USGS website) and performed key informant interviews, focal group discussions, and field data collection to validate the result. Between 1990 and 2017, bare land, forest, and water bodies declined, whereas farmland, brushland, and grasslands increased.

In their work, Berihun et al. [10] looked at LULCCs and drivers for contrasting the alterations of the agro-ecological conditions of the Guder, Aba Gerima, and Debatie watersheds. For this study, they used images acquired in 1982 and 2017, which were visually interpreted via the ArcGIS 10.4 software, with support information coming from key informant interviews and field observations. These three catchments were classified into six 
LULC calluses: bare land, cultivated land, forest, grazing land, settlement, and plantations. In 1982, the forest was the dominant LULC class in Guder and Aba Gerima watershed, while the Debatie watershed was mostly covered by bushes. During the observed period forest land, bushland, and grazing land decreased, while cultivated land increased significantly in all the studied watersheds. As major drivers of such variations, the authors identified both the population growth and the associated changes in farming practices.

The study in [13] was on the Andassa watershed, which is located within the Blue Nile Basin. In this case, a hybrid classification technique was applied, combining unsupervised and supervised classification methods, via ERDAS Imagine 2014 and ArcGIS 10.3 software. The watershed was classified into five LULC classes: cultivated land, forest, shrubland, grassland, and built-up area. This study was intended to analyse first the LULC changes from 1985 to 2015 and then use a model validated on that period to predict the future state in 2030 and 2045, through a cellular automata Markov (CA-Markov) model. The result shows cultivated land and built-up area were of LULC class were increased while forest, shrubland, and grassland were decreased. Similarly, the increase of cultivated land and built-up area, and the withdrawal of forest, shrubland, and grassland were forecasted as continuing in 2030 and 2045.

Andualem and Gebremariam [37] focused on the impact of LULCCs on streamflow and sediment yield in the Gilgel Abay watershed, Lake Tana sub-basin. In their work, three reference years were selected $(1986,2000,2011)$, and the study area was classified using five LULC classes: cultivated area, water body, grassland, forest, shrubland, by using both ERDAS Imagine and ArcGIS software. During the last 25 years, the land covered by agricultural activities increased significantly, whereas waterbody, grassland, forest, and shrubland decreased.

Getachew and Melesse [38] used a maximum likelihood supervised method with ERDAS Imagine and ArcGIS to evaluate the effect of LULCC on the hydrology of the Angereb Watershed. The area was classified into pasture land, forest, built-up, rangeland, agriculture, and water body, considering the years 1985 and 2011. To validate the analysis, the authors used ground truth data acquired during field campaigns. Comparing the 2011 situation with 1985, it is possible to observe that the built-up and agricultural land increased by $860 \%$ and $20.72 \%$, respectively, while pasture land, forest, and rangeland decreased by around $301 \%, 29 \%$, and $1.4 \%$, respectively, and water body remained almost constant. This study showed one of the most significant examples of the increasing human pressure in Ethiopia, which required the transformation of the region from a natural environment to an anthropised one, with most of the region covered by agricultural activities and settlements.

To evaluate LULC dynamics in the Beressa watershed, located in the north central Highlands, Meshesha et al. [39] used images from 1984 and 2015, analysed through the ArcGIS10.2.2 and ERDAS Imagine14 software. They classified the basin into six classes by using a maximum likelihood classification method and validated the outcomes with information derived from focus group discussions and informal interviews with local citizens. The study pointed out that, during the studied period, farmland, settlement, forest land, and water body expanded, whereas grazing land and bare land were reduced.

The situation of the Gelana sub-watershed, northern Highlands, in 1964, 1986, and 2014, was studied by Miheretu et al. [40]. To classify the study area, a maximum likelihood supervised classification method was implemented in ERDAS Imagine9.1, while reference data points were collected using a GPS for accuracy assessment. The Gelana sub-watershed was classified into seven LULC classes: forest, shrubland, cultivated and rural settlement land, grassland, bare land, urban built-up area, and wetland. The result revealed that from 1964 to 2014, shrubland, cultivated and rural settlement, grassland, bare land, and urban builtup area expanded at a rate of $24 \%, 7 \%, 31 \%, 248 \%$, and $1423 \%$, respectively. On the other hand, forest and wetland decreased by around $64 \%$ and $55 \%$, respectively. Additionally, in this case, a dramatic increment of urban and built-up areas is recognisable. 
The study reported in [41] was conducted in the Central Rift Valley Region, to assess the spatial and temporal LULCC that affected the Arsi Negele District in the period 1973-2010. Remote sensing images, analysed via ERDAS Imagine 8.7 and ArcGIS, were used for LULC classification, and the outcomes were validated using key informant interviews and field evidence. In this case, the study area was classified into five LULC classes: bare land, grazing land, cultivated land, shrubland, and Acacia woodland. During the study's $37-y e a r$ period, bare land, cultivated land, and shrubland expanded by $18 \%$, $37 \%$, and $47 \%$, respectively, while grazing land and Acacia woodland declined by $53 \%$ and $36 \%$, respectively.

Sewnet and Abebe [42] studied the Koga watershed, located in northwest Ethiopia. Their research looked at understanding the implication of LULCC on the watershed degradation, observed during the period 1973-2011. For doing that, they used four reference years $(1973,1986,1995,2011)$, and a hybrid unsupervised and supervised classification approach. The classification results obtained by ERDAS and ArcGIS were integrated with field evidence measured using GPS systems, and structured household questionnaires, focus group discussions, and interview with key informants. The Koga watershed was classified into cultivated and settlement areas, forest, brushland, grassland, wetland, and water body. The authors' analysis indicated an increment in areas covered by cultivated and settlement, forest, and water bodies, while bushland, grassland, and wetland decreased significantly.

Table 3 summarises the results reported above and allows for a comparison between the outcomes reported in the different articles.

Table 3. Land use land cover change considered in the reviewed articles.

\begin{tabular}{|c|c|c|c|c|c|c|c|c|c|c|c|c|c|c|c|c|c|c|c|c|c|c|c|c|c|c|}
\hline \multirow{2}{*}{ LULC Class } & \multicolumn{24}{|c|}{ Article } & \multirow[t]{2}{*}{ Total } & \multirow[t]{2}{*}{ Percentage (\%) } \\
\hline & 1 & 2 & 3 & 4 & 5 & 6 & 7 & 8 & 9 & 10 & 11 & 1213 & 14 & 15 & 16 & 17 & 18 & 19 & 20 & 21 & 22 & 23 & 24 & 25 & & \\
\hline agricultural land & + & + & & + & + & + & + & + & + & + & + & $+\quad-$ & + & + & + & + & + & + & + & + & + & + & + & + & $23+, 1-$ & $95.83 \%+, 4.17 \%-$ \\
\hline forest & - & - & & - & + & - & - & - & - & - & - & $-\quad-$ & - & - & - & - & - & - & - & - & + & - & - & + & $3+, 21-$ & $12.5 \%+, 87.5 \%-$ \\
\hline grazing & - & - & & - & - & + & & - & & + & - & -+ & - & - & - & + & - & - & - & - & - & + & - & - & $5+, 17-$ & $22.73 \%+, 77.27 \%-$ \\
\hline waterbody & + & + & & & - & & + & & & + & & & & & + & - & & & - & $\mathrm{C}$ & + & & & + & $7+, 3-, C$ & $\begin{array}{c}63.64 \%+, 27.27 \%- \\
9.01 \%\end{array}$ \\
\hline swamp/wetland & - & - & & & & & - & & & & & & - & & + & & & & & & & - & & $=$ & $1+, 6-$ & $14.29 \%+, 85.71 \%-$ \\
\hline shrub & - & & & - & & & & - & + & - & - & - & - & + & + & + & & - & - & & & + & + & - & $6+, 10-$ & $37.5 \%+, 62.5 \%-$ \\
\hline commercial farm & & + & & & & & & & & & & & + & & & & & & & & & & & & $2+$ & $100 \%$ \\
\hline $\begin{array}{c}\text { Built- } \\
\text { up/settlement }\end{array}$ & & + & & + & + & & + & & & + & + & + & + & & & & & + & & + & + & + & & & $13+$ & $100 \%$ \\
\hline rangeland & & - & & & & & & & $\mathrm{C}$ & & & & & & & & & & & - & & & & & $1+, 1-, 1 C$ & $\begin{array}{c}33.33 \%+ \\
33.33^{*} \\
33.33 \% \mathrm{C}\end{array}$ \\
\hline bare/rock outcrop & & & & & - & $\mathrm{C}$ & - & & $\mathrm{C}$ & + & + & + & & & & - & - & & & & - & + & + & & $5+, 4-, 2 \mathrm{C}$ & $\begin{array}{c}45.45 \%, 36.36 \%- \\
18.18 \% \mathrm{C}\end{array}$ \\
\hline
\end{tabular}

In Table 3, + indicates an increased land cover class, - indicates a decreased land cover class, and $\mathrm{C}$ indicates a constant land cover class, while the free space indicates that no LULCCs were considered in the specific article.

Following the methodology reported in Section 3, it is possible to observe that, among Ethiopian basins, there is a clear increment in areas devoted to agriculture, commercial farms, and settlements, as well as water bodies and bare/rock outcrop land (Figure 3). The increment of this latter class is due to the construction of new human-made reservoirs, mainly for hydropower and agricultural use. During the last decades, the increasing human pressure affected negatively the natural environment, as is visible in the significant decline of forests, swamps, and wetlands. 


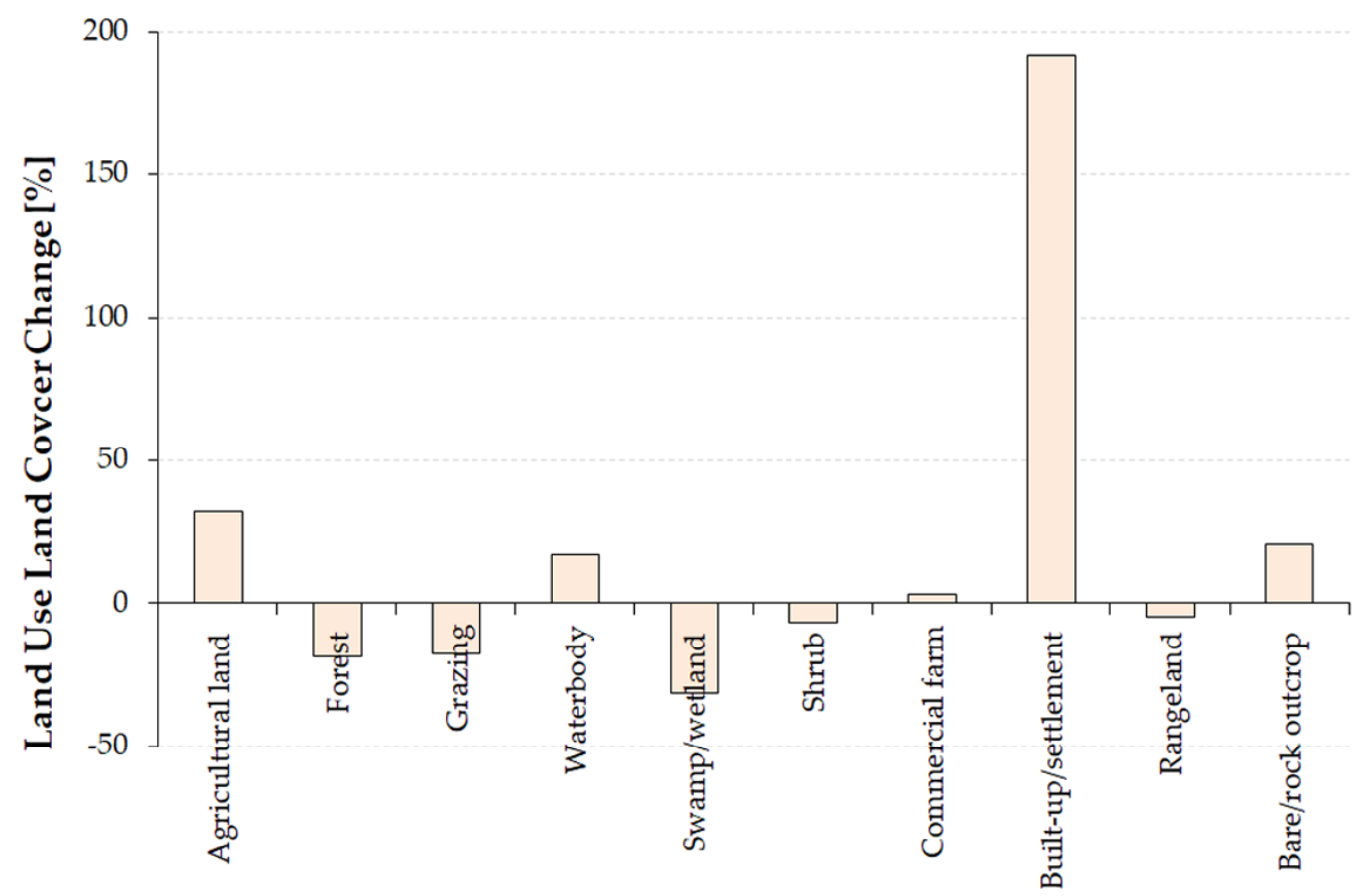

Figure 3. Land use land cover changes percentage in Ethiopia.

Agricultural land use increased in all the analysed studies except in [32], while forest land use decreased in all the study cases, except for the increment pointed out by [16]. In detail, agricultural land, waterbody, commercial farm, bare/rock outcrop and builtup/settlement increased by around $32 \%, 17 \%, 3 \%, 21 \%$ and $191 \%$, respectively. On the contrary, forest, grazing land, swamp/wetland, shrubland, and rangeland decreased by around $19 \%, 18 \%, 32 \%, 7 \%$, and $5 \%$, respectively (Figure 3 ).

\section{Discussion}

The results of the reviewed articles indicated that LULCCs for the past decades, as derived from the analysis of satellite imagery, were in accordance with field evidence (e.g., ground truth data and focus group discussion). In fact, most of the authors used techniques such as key informant interviews, focal group discussions, and field data collection to study the socio-economy and to validate the results obtained from Landsat data. In the majority of the analysed works, the key informant interviews were conducted involving the elder peoples, aged greater than 60 years old, to derive more consistent information on the history of the study area. Focal group discussions were performed with household farmers and local peoples, regardless of their age and social position. During the field data collection, the authors used GPS information to validate the results.

The outcomes presented in this review article agree with the analysis performed by Lambin et al. [8], who reviewed different studies covering a wider spatial scale. They argued that the pathways of LULCCs are a result of globalisation processes, intended as the [cide with the incorporation of a region into an expanding world economy, as is visible also for the Ethiopian case study. In this case, the expansion of internal and transnational markets influenced the LULC, involving deforestation, rangeland modifications, agricultural intensification, and urbanisation, since economic growth and persistent urbanisation are unavoidable global phenomena that initiate urban encroachment into agricultural lands $[43,44]$.

Theoretical and numerical modelling can represent a very helpful tool for meeting land management needs, and for better assessing and projecting the future role of LULCCs in the functioning of the Earth's system [45]. To be effective, such models should be able to reproduce the main drivers of land use change, accounting for their scale dependency, predicting both the location and the quantity of LULCC, incorporating all possible bio- 
physical feedbacks [44-48]. Numerical modelling approaches can benefit from the recent development in computational resources and the availability of remotely sensed data. Cloud computing services such as Google Earth Engine can provide information on the long-term LULCCs over a wide area [49], creating an extensive dataset to calibrate and validate numerical models.

The reviewed articles addressed LULCCs with high detail, providing significant evidence at the watershed scale. In fact, all the studied basins experienced a general trend towards 'more people more erosion', with implications in terms of land degradation and hydrological response. However, there is a lack of (i) detailed investigations of the implications of LULCCs on land erosion and basin-wide hydrology and (ii) studies focused on forecasting future trends of LULCCs. Therefore, there is the need to tackle both these aspects in detail to develop adequate strategies for land management and monitoring systems needed for assuring a sustainable Ethiopia for the next decades.

In this sense, a few studies tried to simulate the future evolution of LULCCs across Ethiopian basins, mainly using cellular automata and Markov chain models, which permit to account for both physical and socioeconomic drivers of LULC dynamics [13,50-52]. Despite the challenges associated with data and model validation, these authors have shown that such kind of studies is needed to support governmental strategies, both in rural and urban areas. They pointed out that the increase in built-up areas is an indication of the rapid population growth, and this may remain a challenge unless environmentally friendly policies on land use will be implemented to harmonise the demand and diminish the impacts that arise from it.

\section{Conclusions}

The review of 25 articles very recent articles on LULCCs in Ethiopia pointed out that the predominant methods to classify lands are unsupervised and maximum likelihood supervised classification, generally performed via GIS and ERDAS Imagine software. To validate the information retrieved from satellite images, the majority of the studies used key informant interviews, focal group discussions, and ground truth data. Among the classes analysed, there is a large variability, but the most common ones are agricultural land, forest, grazing land, water body, swamp area, shrubland, barren land, etc.

A comparison between the articles indicates that, in most of the studied basins, agricultural land, water body, commercial farm, built-up/settlement, and bare/rock outcrop increased during the last decades in a dramatic manner, while the area covered by forest, grazing land, and shrubland decreased. Such changes are mostly connected with increasing human pressure on the Ethiopian environment, driven by the need of improving the socioeconomic situation of the local population.

As pointed out in discussing the single articles, the monitoring on LULCCs can be performed with a number of techniques and software, eventually driving to dissimilar o very site-specific results. For the future, therefore, there is a need for agreeing on a common methodology, aiming to obtain consistent results worldwide.

Author Contributions: Conceptualisation, M.S.R. and M.N.; writing—original draft preparation, M.S.R. and M.N.; literature review, M.S.R. and D.A.; manuscript revision, M.S.R., M.N. and D.A.; supervision, M.N.; project administration, M.N.; funding acquisition, M.N. All authors have read and agreed to the published version of the manuscript.

Funding: This research was funded by NCN National Science Centre Poland-call PRELUDIUM BIS-1, Grant Number 2019/35/O/ST10/00167. Project website: https:/ / sites.google.com/view/lulcfincha/home.

Data Availability Statement: The data presented in this study are available on request from the corresponding author.

Conflicts of Interest: The authors declare no conflict of interest. The funder had no role in the design of the study; in the collection, analyses, or interpretation of data; in the writing of the manuscript; in the decision to publish the results. 


\section{References}

1. IPCC. Land Use, Land-Use Change, and Forestry; Watson, R.T., Noble, I.R., Bolin, B., Ravindranath, N.H., Verardo, D.J., Dokken, D.J., Eds.; Cambridge University Press: Cambridge, UK, 2000; p. 375.

2. Mariye, M.; Mariyo, M.; Changming, Y.; Teffera, Z.L.; Weldegebrial, B. Effects of land use and land cover change on soil erosion potential in Berhe district: A case study of Legedadi watershed, Ethiopia. Int. J. River Basin Manag. 2020, 1-13. [CrossRef]

3. Maitima, J.M.; Mugatha, S.M.; Reid, R.S.; Gachimbi, L.N.; Majule, A.; Lyaruu, H.; Mugisha, S. The linkages between land use change, land degradation and biodiversity across East Africa. Afr. J. Environ. Sci. Technol. 2009, 3, 310-325.

4. Haregeweyn, N.; Tesfaye, S.; Tsunekawa, A.; Tsubo, M.; Meshesha, D.T.; Adgo, E.; Elias, A. Dynamics of land use and land cover and its effects on hydrologic responses: Case study of the Gilgel Tekeze catchment in the highlands of Northern Ethiopia. Environ. Monit. Assess. 2014, 187, 1-14. [CrossRef]

5. Goldewijk, K.K.; Ramankutty, N. Land cover change over the last three centuries due to human activities: The availability of new global data sets. GeoJournal 2004, 61, 335-344. [CrossRef]

6. Chang, Y.; Hou, K.; Li, X.; Zhang, Y.; Chen, P. Review of Land Use and Land Cover Change research progress. IOP Conf. Ser. Earth Environ. Sci. 2018, 113, 012087. [CrossRef]

7. Alemayehu, F.; Tolera, M.; Tesfaye, G. Land use land cover change trend and its drivers in Somodo watershed south western, Ethiopia. Afr. J. Agric. Res. 2019, 14, 102-117.

8. Lambin, E.F.; Turner, B.L.; Geist, H.J.; Agbola, S.B.; Angelsen, A.; Bruce, J.W.; Coomes, O.T.; Dirzo, R.; Fischer, G.; Folke, C.; et al. The causes of land-use and land-cover change: Moving beyond the myths. Glob. Environ. Chang. 2001, 11, 261-269. [CrossRef]

9. Tolessa, T.; Dechassa, C.; Simane, B.; Alamerew, B.; Kidane, M. Land use/land cover dynamics in response to various driving forces in Didessa sub-basin, Ethiopia. GeoJournal 2020, 85, 747-760. [CrossRef]

10. Berihun, M.L.; Tsunekawa, A.; Haregeweyn, N.; Meshesha, D.T.; Adgo, E.; Tsubo, M.; Masunaga, T.; Fenta, A.A.; Sultan, D.; Yibeltal, M. Exploring land use/land cover changes, drivers and their implications in contrasting agro-ecological environments of Ethiopia. Land Use Policy 2019, 87, 104052. [CrossRef]

11. Guzha, A.; Rufino, M.; Okoth, S.; Jacobs, S.; Nobrega, R. Impacts of land use and land cover change on surface runoff, discharge and low flows: Evidence from East Africa. J. Hydrol. Reg. Stud. 2018, 15, 49-67. [CrossRef]

12. Marchant, R.; Richer, S.; Boles, O.; Capitani, C.; Courtney-Mustaphi, C.J.; Lane, P.; Prendergast, M.E.; Stump, D.; De Cort, G.; Kaplan, J.O.; et al. Drivers and trajectories of land cover change in East Africa: Human and environmental interactions from 6000 years ago to present. Earth Sci. Rev. 2018, 178, 322-378. [CrossRef]

13. Gashaw, T.; Tulu, T.; Argaw, M.; Worqlul, A.W. Evaluation and prediction of land use/land cover changes in the Andassa watershed, Blue Nile Basin, Ethiopia. Environ. Syst. Res. 2017, 6, 17. [CrossRef]

14. Tefera, M.M. Land-use/land-cover dynamics in Nonno district, central Ethiopia. J. Sustain. Dev. Afr. 2011, 13, 123-141.

15. Demeke, M.; Guta, F.; Ferede, T. Agricultural Development in Ethiopia: Are There Alternatives to Food Aid? Department of Economics, Addis Ababa University 2004. Available online: sarpn.org.za/documents/d0001583/FAO2005_Casestudies_Ethiopia. pdf (accessed on 15 May 2021).

16. Gebreslassie, H. Land Use-Land Cover dynamics of Huluka watershed, Central Rift Valley, Ethiopia. Int. Soil Water Conserv. Res. 2014, 2, 25-33. [CrossRef]

17. Dadi, D.; Azadi, H.; Senbeta, F.; Abebe, K.; Taheri, F.; Stellmacher, T. Urban sprawl and its impacts on land use change in Central Ethiopia. Urban For. Urban Green. 2016, 16, 132-141. [CrossRef]

18. Dibaba, W.T.; Demissie, T.A.; Miegel, K. Drivers and Implications of Land Use/Land Cover Dynamics in Finchaa Catchment, Northwestern Ethiopia. Land 2020, 9, 113. [CrossRef]

19. Romanowicz, R.J. The impacts of changes in climate and land use on hydrological processes. Acta Geophys. 2017, 65, 785-787. [CrossRef]

20. Dinka, M.O.; Klik, A. Effect of land use-land cover change on the regimes of surface runoff-the case of Lake Basaka catchment (Ethiopia). Environ. Monit. Assess. 2019, 191, 278. [CrossRef]

21. Othow, O.O.; Gebre, S.L.; Gemeda, D.O. Analyzing the Rate of Land Use and Land Cover Change and Determining the Causes of Forest Cover Change in Gog District, Gambella Regional State, Ethiopia. J. Remote Sens. GIS 2017, 6, 1-13. [CrossRef]

22. Grover, D.K.; Temesgen, A. Enhancing Land-Use-Efficiency through Appropriate Land Policies in Ethiopia. 2006. Available online: https:/ /ideas.repec.org/p/ags/iaae06/25615.html (accessed on 16 May 2021).

23. Bekele, T.; Tsegaye, B. Effect of Land Use and Land Cover Changes on Soil Erosion in Ethiopia. Int. J. Agric. Sci. Food Technol. 2019, 5, 026-034. [CrossRef]

24. Reusing, M.; Schneider, T.; Ammer, U. Modelling soil loss rates in the Ethiopian Highlands by integration of high resolution MOMS-02/D2-stereo-data in a GIS. Int. J. Remote Sens. 2000, 21, 1885-1896. [CrossRef]

25. Ebabu, K.; Tsunekawa, A.; Haregeweyn, N.; Adgo, E.; Meshesha, D.T.; Aklog, D.; Masunaga, T.; Tsubo, M.; Sultan, D.; Fenta, A.A.; et al. Effects of land use and sustainable land management practices on runoff and soil loss in the Upper Blue Nile basin, Ethiopia. Sci. Total Environ. 2019, 648, 1462-1475. [CrossRef] [PubMed]

26. Plant Genetic Resources Center. In Proceedings of the Country Report to the FAO International Technical Conference on Plant Genetic Resources, Rome, Italy, 19-30 June 1995.

27. Suryabhagavan, K.V. GIS-based climate variability and drought characterization in Ethiopia over three decades. Weather Clim. Extrem. 2017, 15, 11-23. [CrossRef] 
28. Betru, T.; Tolera, M.; Sahle, K.; Kassa, H. Trends and drivers of land use/land cover change in Western Ethiopia. Appl. Geogr. 2019, 104, 83-93. [CrossRef]

29. Biazin, B.; Sterk, G. Drought vulnerability drives land-use and land cover changes in the Rift Valley dry lands of Ethiopia. Agric. Ecosyst. Environ. 2013, 164, 100-113. [CrossRef]

30. Ayana, A.B.; Kositsakulchai, E. Land use change analysis using remote sensing and Markov Modeling in Fincha watershed, Ethiopia. Agric. Nat. Resour. 2012, 46, 135-149.

31. Ayana, A.B.; Edossa, D.; Kositsakulchai, E. Modeling the effects of land use change and management practices on runoff and sediment yields in Fincha watershed, Blue Nile. OIDA Int. J. Sustain. Dev. 2014, 7, 75-88.

32. Hailu, A.; Mammo, S.; Kidane, M. Dynamics of land use, land cover change trend and its drivers in Jimma Geneti District, Western Ethiopia. Land Use Policy 2020, 99, 105011. [CrossRef]

33. Tolessa, T.; Senbeta, F.; Kidane, M. The impact of land use/land cover change on ecosystem services in the central highlands of Ethiopia. Ecosyst. Serv. 2017, 23, 47-54. [CrossRef]

34. Alemu, B.; Garedew, E.; Eshetu, Z.; Kassa, H. Land use and land cover changes and associated driving forces in north western lowlands of Ethiopia. Int. Res. J. Agric. Sci. Soil Sci. 2015, 5, 28-44.

35. Fisseha, G.; Gebrekidan, H.; Kibret, K.; Yitaferu, B.; Bedadi, B. Analysis of land use/land cover changes in the Debre-Mewi watershed at the upper catchment of the Blue Nile Basin, North West Ethiopia. J. Biodivers. Environ. Sci. 2011, 1, 184-198.

36. Mussa, M.; Teka, H.; Mesfin, Y. Land use/cover change analysis and local community perception towards land cover change in the lowland of Bale rangelands, Southeast Ethiopia. Int. J. Biodivers. Conserv. 2017, 9, 363-372.

37. Andualem, T.G.; Gebremariam, B. Impact of land use land cover change on stream flow and sediment yield: A case study of Gilgel Abay watershed, Lake Tana sub-basin, Ethiopia. Int. J. Technol. Enhanc. Merg. Eng. Res. 2015, 3, $28-42$.

38. Getachew, H.E.; Melesse, A.M. The impact of land use change on the hydrology of the Angereb Watershed, Ethiopia. Int. J. Water Sci. 2012, 1, 6.

39. Meshesha, T.W.; Tripathi, S.K.; Khare, D. Analyses of land use and land cover change dynamics using GIS and remote sensing during 1984 and 2015 in the Beressa Watershed Northern Central Highland of Ethiopia. Model Earth Syst. Environ. 2016, 2, 1-12. [CrossRef]

40. Miheretu, B.A.; Yimer, A.A. Land use/land cover changes and their environmental implications in the Gelana sub-watershed of Northern highlands of Ethiopia. Environ. Syst. Res. 2017, 6, 7. [CrossRef]

41. Molla, M.B. Land use/land cover dynamics in the central rift valley region of Ethiopia: Case of Arsi Negele District. Afr. J. Agric. Res. 2015, 10, 434-449.

42. Sewnet, A.; Abebe, G. Land use and land cover change and implication to watershed degradation by using GIS and remote sensing in the Koga watershed, North Western Ethiopia. Earth Sci. Inform. 2017, 11, 99-108. [CrossRef]

43. Azadi, H.; Ho, P.; Hasfiati, L. Agricultural land conversion drivers: A comparison between less developed, developing and developed countries. Land Degrad. Dev. 2010, 22, 596-604. [CrossRef]

44. Paül, V.; McKenzie, F.H. Peri-urban farmland conservation and development of alternative food networks: Insights from a case-study area in metropolitan Barcelona (Catalonia, Spain). Land Use Policy 2013, 30, 94-105. [CrossRef]

45. Agarwal, C.; Green, G.M.; Grove, J.M.; Evans, T.P.; Schweik, G.M. A Review and Assessment of Land-Use Change Models. Dynamics of Space, Time and Human Choice. Bloomington and South Burlington, Center for the Study of Institutions, Population and Environmental Change, Indiana University and USDA Forest Service. CIPEC Collab. Rep. Ser. 2001, 1. [CrossRef]

46. Mondal, M.S.; Sharma, N.; Kappas, M.; Garg, P.K. Modeling of spatio-temporal dynamics of LULC-A review and assessment. J. Geomat. 2012, 6, 93-103.

47. Veldkamp, A.; Lambin, E. Predicting land-use change. Agric. Ecosyst. Environ. 2001, 85, 1-6. [CrossRef]

48. Nones, M. On the main components of landscape evolution modelling of river systems. Acta Geophys. 2020, 68, 459-475. [CrossRef]

49. Midekisa, A.; Holl, F.; Savory, D.J.; Andrade-Pacheco, R.; Gething, P.W.; Bennett, A.; Sturrock, H. Mapping land cover change over continental Africa using Landsat and Google Earth Engine cloud computing. PLoS ONE 2017, 12, e0184926. [CrossRef] [PubMed]

50. Gidey, E.; Dikinya, O.; Sebego, R.; Segosebe, E.; Zenebe, A. Cellular automata and Markov Chain (CA_Markov) model-based predictions of future land use and land cover scenarios (2015-2033) in Raya, northern Ethiopia. Model Earth Syst. Environ. 2017, 3, 1245-1262. [CrossRef]

51. Hishe, S.; Bewket, W.; Nyssen, J.; Lyimo, J. Analysing past land use land cover change and CA-Markov-based future modelling in the Middle Suluh Valley, Northern Ethiopia. Geocarto Int. 2020, 35, 225-255. [CrossRef]

52. Mohamed, A.; Worku, H. Simulating urban land use and cover dynamics using cellular automata and Markov chain approach in Addis Ababa and the surrounding. Urban Clim. 2020, 31, 100545. [CrossRef] 